\title{
Perceived Roles of Skills in Growth and Transformation of Ready Made Garments and Pharmaceutical Industries in Bangladesh: Results from an Industry Survey
}

\section{Md. Abul Kalam ${ }^{\star}$ Sheikh Shahana Shimu}

${ }^{\prime}$ Research Fellow, BRAC IED, BRAC University, Bangladesh.

Email:kalam26@gmail.com Tel:+8801715838170

'Senior Research Associate, BRAC IED, BRAC University, Bangladesh.

Email:sheith_shimu@yahoo.com Tel: +8801552374396

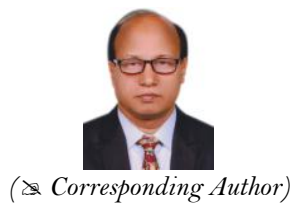

Abstract

This article examines the contribution of Technical and Vocational Education and Training (TVET) programs to growth and transformation in the Ready Made Garments (RMG) and Pharmaceutical industries in Bangladesh as perceived by the industries through a company survey with 100 RMG and 61 Pharmaceuticals. It identifies a missing link between skill development through TVET and the needs of industry in Bangladesh. Results show that, with the exception of pre-employment TVET for technicians and higher management, on average less than $20 \%$ of the companies had workers with pre- and in-employment TVET across all occupational levels. This indicates that TVET providers better fulfil the needs of industry for a smaller number of employees at mid- and higher management level compared to TVET for large numbers of employees at lower levels of general workers, operators and supervisors. It concludes that establishing strong collaboration and partnerships between government, industry and TVET institutions is necessary to harness human resources for employment and development through the world of work.
Citation | Md. Abul Kalam; Sheikh Shahana Shimu (2020). Perceived Roles of Skills in Growth and Transformation of Ready Made Garments and Pharmaceutical Industries in Bangladesh: Results from an Industry Survey. Asian Journal of Education and Training, 6(4): 671-682.

History:

Received: 29 October 2020

Revised: 18 November 2090

Revised: 18 November 2020

Accepted: 2 December 2020

Licensed: This work is licensed under a Creative Commons Attribution 3.0 License (cc)

Publisher: Asian Online Journal Publishing Group
Acknowledgement: The data for this article stems from "Skills-for-Industry", Research for Development project, https://phzh.ch/en/Research/skills-forindustry/, financed by the Swiss Agency for Development and Cooperation industry/, financed by the Swiss Agency for Development and Cooperation
(SDC) and the Swiss National Science Foundation (SNSF). As part of "Skills(SDC) and the Swiss National Science Foundation (SNSF). As part of "Skills-
for-Industry", a large-scale company survey was implemented in six countries. Authors' sincere appreciation goes to Markus Maurer, Joe Gazeley, Andrea Marks, Hannes Teutoburg-Weiss and Dr. Atonu Rabbani for support and comments, feedback on and reviewing the manuscript at different stages in developing this article.

Funding: This study received no specific financial support

Competing Interests: The authors declare that they have no conflict of interests.

Transparency: The authors confirm that the manuscript is an honest, accurate, and transparent account of the study was reported; that no vital features of the study have been omitted; and that any discrepancies from the study as planned have been explained.

Ethical: This study follows all ethical practices during writing.

\section{Contents}

1. Introduction 


\section{Contribution of this paper to the literature}

This study contributes to existing literature by examining extent of the contribution of TVET to the growth and transformation in industries with reference to two sectors of industries in Bangladesh.

\section{Introduction}

This research examines the contribution of Technical and Vocational Education and Training (TVET) programs to the growth and transformation of the Ready Made Garments (RMG) and Pharmaceutical industries in Bangladesh as perceived through industry surveys. It is recognized in the academic literature that economic development requires extensive industrialization, particularly in the Asian context. At the national level Bangladesh is no exception and has gradually shifted its focus away from the agricultural sector and emphasized industrial development in order to achieve economic development. This requires a skilled labour force which in turn suggests that industry would focus resources on TVET, to accelerate the productivity increase of the labour force needed achieve economic development. However, our results show that, aside from technicians and managers, on average less than $20 \%$ of the companies surveyed had workers with pre- and in-employment TVET training. TVET programs for mid- and higher-level occupations (technician and higher management) did contribute to filling the skills needs of these companies, however, only pre-employment TVET contributed significantly. There has been a moderate or very weak relationship between the extent of the contribution of TVET programs and the extent of growth and transformation. This research sheds light on the challenges facing TVET programs in Bangladesh and seeks to identify potential reasons for the lack of alignment between TVET and industries in Bangladesh, identified by skills shortages, a skills-gap, and a skills mismatch.

There has been a significant structural economic shift, away from traditional agriculture towards exportoriented manufacturing and the services sector. This has increased demand for skilled workers, particularly in export-oriented manufacturing industries. Education has been identified as an important determinant of economic growth. Higher levels of educational attainment lead to a more skilled and productive workforce, producing more efficiently a higher standard of goods and services, which in turn forms the basis for faster economic growth and rising living standards. To benefit from this as well as from demographic dividend, productivity increase of the labour force needs to be accelerated with an emphasis on soft skills and market-responsive TVET.

The overall objective of the study was to examine the relationship between TVET programs and the growth and transformation of the RMG and Pharmaceutical industries in Bangladesh as perceived by managers in the industry. The specific objectives were:

- To assess growth in industries from 2012 to 2017 in terms of sales, employment and income (workers' salary).

- To examine transformation of industries from 2012 to 2017 in terms of changes in technology, product and work organization.

- To identify workers' skills gaps/needs due to the above changes.

- To assess the contribution of TVET programs to meeting the skills demands/needs at different occupational levels perceived by the industries.

\subsection{Bangladesh Context}

For Bangladesh to attain the status of middle-income country by 2024, special emphasis must be given to the rapid expansion of the industrial sector as well as the creation of skilled manpower. The policy framework for this is the Vision 2021 plan which envisages that by 2021, Bangladesh will achieve high-performing growth supported by advanced and innovative technology with prices of commodities stabilized, income and human poverty brought to a minimum, health and education for all secured and capacity building combined with creativity enhanced, social justice established, interpersonal and regional income disparity reduced, all forms of discrimination eliminated, participatory democracy firmly rooted, and a capacity to tackle the adverse effects of climate change achieved. Information and communication technology will, by that time, also take the country to new heights of excellence, bringing a new 'Digital Bangladesh' identity (Government of Bangladesh, 2010a).

Since independence, the country has gone through a structural transformation by moving from dependence on agriculture to reliance on industry and service sectors. According to figures from Raihan and Khan (2020) the share of agriculture dropped from about half of total GDP during the 1970s to about one-third during the 1980s. They outline that this further declined from approximately $30 \%$ in 1990 to $13 \%$ in 2017 . On the other hand, the industrial sector's share in growth has been increasing over the years. Immediately after independence, the contribution of the industrial sector was insignificant. Again, according to Raihan and Khan (2020) this rose from $20 \%$ in the 1980 s to $28 \%$ in 2017. In Bangladesh the dominant economic sector in terms of output is 'services' which accounted for $55 \%$ of GDP in 2018 (Raihan \& Khan, 2020).

Two industries, RMG and Pharmaceuticals, were selected for this study because they are priority industries in the national industrial policy of Bangladesh (Government of Bangladesh, 2016a). The growth of the industrial sector has been heavily driven by the growth of the RMG sector which is now the largest within the industrial sector in Bangladesh and plays a major role in generating foreign currency and generating employment (World Bank, 2018). RMG started its journey in Bangladesh in the late 1970s (Mostafa \& Klepper, 2017) with establishment of a new indigenous enterprise called Desh Ltd. In 1979, following partnership with Daewoo Corporation of South Korea which was suffering severely from the quota system. Daewoo took the advantage of Bangladesh's advantageous status under the Multi-Fiber Agreement (MFA) (Mottaleb \& Sonobe, 2011). Although the government hardly recognized the potential of the garment industry in its early days, in 1982, the government of Bangladesh began to provide various incentives to the RMG industry including duty free import of machinery, bonded warehouse facilities and cash incentives (Mottaleb \& Sonobe, 2011). RMG is the highest performing export sector in Bangladesh and accounted for $81 \%$ of the total export earnings in the country, earning around $\$ 2812$ billion in 2016-2017 fiscal year (Export Promotion Bureau, 2017). The export oriented RMG sector transformed the 
economy of Bangladesh with the help of entrepreneurs, domestic fiscal and financial policy support and global market opportunities (Bhattacharya, Raman, \& Raihan, 2002). The Bangladeshi garment industry has experienced a rapid growth in the past 30 years from 40,000 people employed in 1983 in 46 production units to 4 million in 4,500 units in the year 2013 with an average yearly growth rate of 17 percent. Heath and Mobarak (2015). Providentially, Bangladesh got the quota facilities for the Least Developed Countries (LDCs) in exporting its garment products to developed countries that outsourced their ready-made garment production needs. RMG factories are increasingly moving from semiautomatic to more automatic industry using sophisticated machines, technologies and software to facilitate the fast and vast growth of RMG and textile industry. Low liquor dyeing machine, Ozone washing machines, auto trimming, Jacquard machine, SAP, and ERP like technologies have already become popular. Most new generation factories are equipped with sophisticated technologies and able to handle top quality products of diverse styles allowing further competitiveness by keeping unit cost low (BGMEA, undated).

The pharmaceutical industry is one of the fastest growing and developed manufacturing industries in Bangladesh.This infant industry got protection through the National Drug Policy enacted in 1982 to help pharmaceuticals flourish as a strong domestic industry. This policy articulated a vision of self-reliance and priority provision of basic national needs and an attitude of proud defiance against the multinationals - a stance of economic nationalism. The policy succeeded in promoting domestic production and in promoting essential drugs production within Bangladesh (Reich, 1994). The drug policy, which was again revised in 2005, limits import of pharmaceuticals where local products are sufficient which ensured domestic industry access to the large domestic market for pharmaceutical products and safeguarded intellectual property rights on some domestic generic products. Internal demand for better healthcare is increasing due to growing awareness of healthcare options, higher incomes in the country and increasing government expenditure on the health sector. The pharmaceutical industry meets $97 \%$ of demand for medication in the country and the sector employs 115,000 workers (Hossain \& Shoaib, 2014; Sultana, 2016). There are currently 300 active allopathic manufacturing firms working in Bangladesh and the number was around 250 in 2012 (Tazin, 2016). These companies together have 5,300 registered brands which have 8,300 different forms of dosages and strengths (Bhuiyan, Hakim, \& Alam, 2015). The growth rate of the pharmaceutical industry steadily increased from $10.18 \%$ in 2002 to $21.5 \%$ in 2012 (Hossain \& Shoaib, 2014 ). The yearly export performance of this industry is increasing day by day and in 2017 the total exports in this sector stood at 82.11 million dollars to around 100 countries in the world (Export Promotion Bureau, 2017). The pharmaceutical industry also contributes greatly to global value chains by importing 90 percent of its raw materials from around the globe. The pharmaceutical industry is considered a hi-tech industry in Bangladesh. Foreign direct investment stood at 135.4 million USD in 2010 for this industry and it had very high domestic market capitalization capacity (16.49 percent). The pharmaceutical industry is also an $8^{\text {th }}$ priority manufacturing industry sector of Bangladesh according to the 2016 industry policy paper (Government of Bangladesh, 2016b).

\subsection{TVET Literature and Industrial Growth}

Mankiw, Romer, and Weil (1992) explain that the accumulation of human, as well as physical capital, provides an excellent description of economic growth. However, the importance of TVET for economic growth is only gradually receiving attention in government priorities and global debates for education and national development plans (Lee, Har, \& Lee, 2020). The United Nation's 2015 Sustainable Development Goals (SDGs) explicitly includes space for TVET (UN, 2015). Goal 4 of the SDGs aims to "ensure inclusive and equitable quality education and promote lifelong learning opportunities for all” (UN, 2015). It shows the prominence of human development and the necessity to contemplate more seriously skills for life and work. Mcgrath and Powell (2016) highlight the relationship between skills development and sustainable development. They argue that human development and sustainable development must be seen as inseparable by planning and evaluating TVET for its contribution to sustainable development. TVET could contribute to reducing the problems of poverty, injustice and inequality. They conclude that TVET is important to transform skills, work and the world to ensure sustainable development and protect the interests of the individuals that will populate the earth in the future. Jabarullah and Hussain (2019) support that TVET encourages training in essential real-world skillsets namely problem solving, critical thinking, lifelong learning and communication to enhance the skills of the graduates to be well aligned with the dynamic expectations of today's job market. Paton, Fluck, and Scanlan (2018) further explain that TVET usually have no, or low-level entry requirements, compared to the universities which require an academic achievement score that meets the intellectual demands of each course and the completion of twelve years. Hence, TVET is a better alternative than higher education to prepare the graduates equipped with suitable skills in meeting the demands of employers and may help reduce youth unemployment (Asadullah \& Ullah, 2018).

TVET is even more important due to the impact of technological development on the skills required from labour. The third industrial revolution began to develop at the beginning of the $21^{\text {st }}$ century (Petrillo, De Felice, Cioffi, \& Zomparelli, 2018) and is characterized by machine automation through the use of electronics and the application of IT in production processes (Brettel, Friederichsen, Keller, \& Rosenberg, 2014). Globalization, international business, trade and integration with Global Value Chains push businesses/industries, to transform their technology, the products and services they produce and to adapt to ensure their survival. Some pessimists believe that technological advances will be disruptive for employment and jobs while others take the more optimistic view that this will also create new job tasks and occupations. Consequently, estimates for the number of jobs at risk of automation range from Arntz, Gregory, and Zierahn (2016) low estimate of 9\% in the United States to much higher figures of $43 \%$ in the US (Frey \& Osborne, 2013), 57\% for OECD countries and $85 \%$ in Ethiopia (Frey \& Rahbari, 2016; Sungsup, Shrestha, Khatiwada, Yoon, \& Kwon, 2019). Challenging the higher end estimates, Mitra and Sharma (2020) argue that the dampening effect of new technology on absolute employment seems to be rather exaggerated, although the concern may be justified in relative terms or for unskilled labour (Mitra \& Sharma, 2020). This indicates that TVET is increasingly important for low-skilled workers' future job security.

Melaiye, Amuchie, and Glory (2019) argue that education, especially technical and vocational education, has been central to the national development of fast developing countries such as the "Asian Tigers". Generally, education has become the basis for economic growth, political stability and social harmony. Lee et al. (2020) 
propose that this is through improvements in efficiency, productivity and competitiveness which vocational training can provide. TVET also has potential benefits for individuals in terms of self-actualisation and labour market access (Melaiye et al., 2019). Bangladesh's economic future largely depends on adopting training strategies that will ensure the creation of adequate technically skilled, and self-actualised, workers.

\subsection{TVET in Bangladesh}

The main purpose of TVET in Bangladesh is transforming the large youthful population into a skilled workforce that will contribute to industrial growth and productivity (Government of Bangladesh, 2011). Formal TVET programs are mostly regulated by government although some rely on traditional approaches- informal apprenticeships which are accepted in informal businesses but not certified.

TVET in Bangladesh is delivered at three levels of skills development programs: basic, certificate, and diploma, and managed by about 24 ministries and 22 agencies of Bangladesh Government. However, the Directorate of Technical Education, a body of the Ministry of Education, and the Bureau of Manpower, Employment and Training, a body of the Ministry of Expatriates' Welfare and Overseas Employment, play an instrumental role in delivering and organizing TVET (Khan, 2019). The Directorate of Textiles, which is under the Ministry of Textiles and Jute, plays a vital role in organizing vocational training and technical education especially in the field of textiles in Bangladesh. The Bangladesh Technical Education Board (BTEB), an organisation of the Ministry of Education, has authority for the certification of Secondary School Certificate, Vocational (SSC, Voc), Higher Secondary Certificate, Vocational (HSC, Voc) and Diploma Courses. Vocational education and training programs in Bangladesh offer a variety of TVET courses starting from Secondary Level (Class IX) to the Diploma Level. Technical Training Centres (TTCs), Technical Schools and Colleges (TSCs), Polytechnic Institutes, Agricultural Training Institutes, Textile Institutes, Marine Technology Institutes offer TVET courses in Bangladesh. In addition, besides the TVET institutions managed by the Government, there are about 6000 TVET institutions managed by private initiatives across Bangladesh which are involved in organizing a wide range of vocational training courses including the SSC (Voc) and diploma (Bangladesh Bureau of Educational Information and Statistics [BANBEIS], 2019; Khan (2019); Siddiky and Uh (2020).

The TVET sector is governed by the National Skills Development Policy 2011 (Government of Bangladesh, 2011), National Education Policy 2010 (Government of Bangladesh, 2010b); NSDA Act 2018; BTEB Act 2018 (Government of Bangladesh, 2018b), and NFE Act 2014 (Government of Bangladesh, 2014). National strategic plans such as the $7^{\text {th }}$ Five Year Plan (Government of Bangladesh, 2010a, 2015a) and other acts and policies such as the Bangladesh Labour Act 2006 (Government of Bangladesh, 2015b) the Skills and Training Enhancement Project (STEP) (Government of Bangladesh, 2010c) and Skills for Employment Investment Program (SEIP) (Government of Bangladesh, 2015c), National Technical and Vocational Qualifications Framework (NTVQF) (Government of Bangladesh, 2009) are being run across the country to provide training both at worker- and management-levels and equip them with necessary skills. Besides, RMG and Textile Industrial Skills Council (RTISC) and the Centre of Excellence for the Bangladesh Apparel Industries (CEBAI) have been established to facilitate skills development in the country and the 2016 Expatriates Welfare and Overseas Employment Policy (Government of Bangladesh, 2016b) are also supportive of the development of the TVET sector including the employment of TVET graduates. Proper implementation of these policies and acts including the required institutional capacities of the relevant agencies are the key challenges. There are also challenges related to quality, access and equity, and governance (Khan, 2019).

The TVET system in Bangladesh is also facing challenges in responding to the demand for skills from different sectors, especially in the industrial and manufacturing sectors. According to Siddiky and Uh (2020), the TVET sector in Bangladesh is yet to be prioritized and has been facing a number of impediments, including skills shortages, skills-gaps, and a skills mismatch, that is, the mismatch between the supply of skills and the demand for skills (Asian Development Bank, 2011, 2015, 2016; Bangladesh Institute of Development Studies, 2017; Dewan \& Sarker, 2017; Hossain, 2018; Khan, 2019; Mia \& Karim, 2015; Raihan, Lemma, Khondokar, \& Ferdous, 2017; World Bank, 2018). There are three dimensions to this mismatch between the outputs of the TVET system and the needs of industry: first, the trades or technologies being offered through training programs are not relevant to employment; second, the competencies acquired in relation to the requirements of industries or self-employment opportunities are insufficient; and third, a lack of practical experience (Mia \& Karim, 2015). Hence, there is a missing link between skill development and employment, that is, a lack of alignment between TVET and industries in Bangladesh (Siddiky \& Uh, 2020).

\section{Methodology}

2.1. Overall Study Design

The study was conducted using a survey method technique, gathering data from different companies of two industrial sectors in Bangladesh. Due to their importance, the RMG and pharmaceutical industries in Bangladesh were selected for analysis. The samples were selected from the listed industries of Bangladesh Garments Manufacturers and Exporters Association (BGMEA) and Bangladesh Association of Pharmaceutical Industries (BAPI).

\begin{tabular}{c|c|c|c|c}
\multicolumn{7}{c}{ Table-1. The sample distribution by RMG and Pharmaceutical industries. } \\
\hline Industries & Population & Sample size & Survey of companies & Total sample \\
\hline RMG & 3,445 & 400 & 100 & 100 \\
\hline Pharmaceutical & 149 & 149 & 61 & 61 \\
\hline Both & 3,594 & 549 & 161 & 161 \\
\hline
\end{tabular}

2.2. Sampling and Sample Size

Companies were selected through simple random sampling from an updated member list on the BGMEA and BAPI website. Companies which did not fulfil the following requirements of the study were dropped at this stage: 
at least 50 employees (deviations possible depending on industry size/structure), manufacturing companies (excluding trading companies), accessibility (focus on two or three manufacturing hub regions). Sampling groups were then generated based on region, size and, if relevant, sub industry and the sample size calculated so that the sample and population had the same characteristics. We selected 400 RMGs randomly, of which 100 were surveyed, and of the 149 pharmaceuticals which met the criteria, 61 were surveyed (Table 1). After selecting the companies, each company was given a unique identification number to pseudonymize them.

\subsection{Survey Tool}

The survey tool contained 42 items and explored the trends in four themes over the last five years (2012 to 2017). The themes are as follows:

- Industrial growth and transformation: establishment, change in production, technology and organization, sales, export and FDI.

- Requirement of skill: finding employees, including effects on production, growth and transformation.

- Training: pre-job and on-the-job training for the different level of employees and its effects on company skills need.

- Employment: number of employees (male, female), including salary of different levels of staff.

\subsection{Data Collection}

Bangladesh Association of Pharmaceutical Industries (BAPI) and Bangladesh Garment Manufacturers and Exporters Association (BGMEA) provided approval to conduct the study. All respondents/companies were informed about the study objectives and chose to participate. To maintain confidentiality, the respondents were given a unique identification number and the data set was preserved in a protected electronic format with a password. The survey was conducted on the company premises. If the first company sampled from the list would not participate in the survey then the enumerator/s communicated with the next company from the selected extended sample company list, for RMG and pharmaceuticals it was 101/400 and 62/149 respectively.

Data collection took place between December 15, 2018-January 23, 2019 and May 18, 2019-June 20, 2019. In total 15 enumerators ( 11 male; 4 female) were recruited. They received five days of training on industrial survey tools by a researcher from BRAC Institute of Educational development, BRAC University. Enumerators used tablet devices to collect data using koBoToolbox, and they uploaded the data each day. After all data had been uploaded, data were then downloaded from the koBoToolbox website, and the principal researcher cleaned and prepared the datasets for analysis and report writing.

\subsection{Data Analysis}

In this study, univariate and bivariate analysis were applied for descriptive analysis to find the percentage of companies which had undertaken or arranged TVET programs and to find the companies' overall growth and transformation.

\section{Results}

\subsection{Growth and Transformation}

Most companies showed a positive trend in all growth and transformation indicators over the five years examined (2012-2017). Around 87\% of companies (93\% Pharmaceutical and 83\% RMG) reported that their number of employees had increased. Over the same period, $84 \%$ of companies (90\% Pharmaceutical and $80 \%$ RMG) reported that the volume of their sales had increased more than $33 \%$. These two growth indicators show that on average companies in the pharmaceutical sector performed slightly better Figure 1. Changes in technology, products and work organization were found in almost all companies. This could hint, especially for RMG, at specific upgrading strategies of companies in a competitive global market.

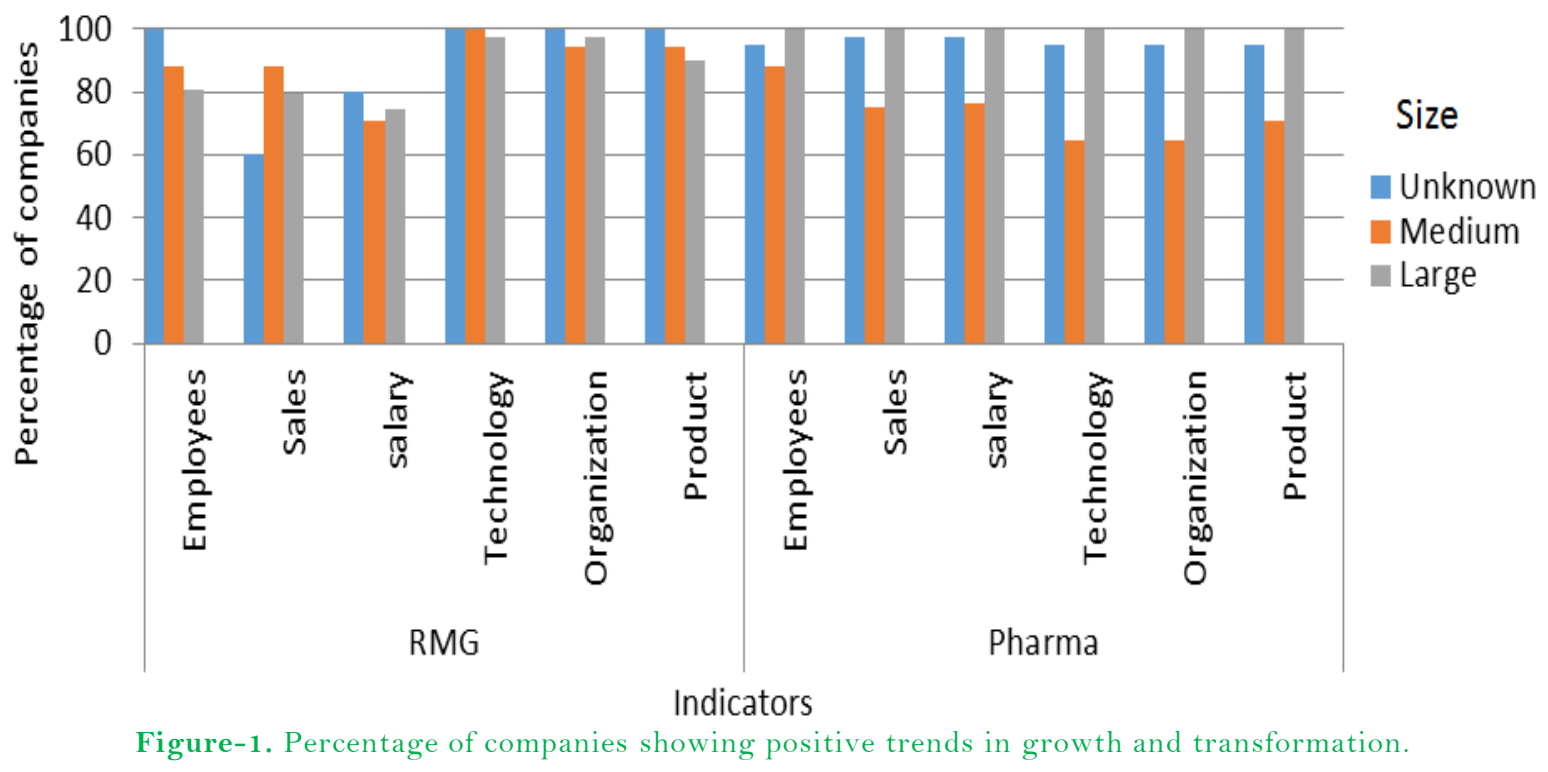

We also found $94 \%$ of companies (87\% Pharmaceutical and $98 \%$ RMG) had integrated more advanced technology into their production processes and manufactured more sophisticated products. As part of this transformation, $93 \%$ of companies (overall) also went through organizational changes ( $87 \%$ Pharmaceutical and $97 \%$ RMG). These three indicators show that transformation is mostly on par between both industries. 


\subsection{Growth, Transformation and Size of the Industries}

When it comes to company size, $27 \%$ of companies in the survey (62\% in pharmaceuticals and $5 \%$ in $\mathrm{RMG}$ ) could not classify due to missing data. Of the companies for which data was available, $21 \%$ (28\% in pharmaceutical and $17 \%$ in RMG) were medium-sized, meaning above 50 employees, and $52 \%$ ( $8 \%$ in pharmaceutical and $78 \%$ in RMG) were large (above 250 employees).

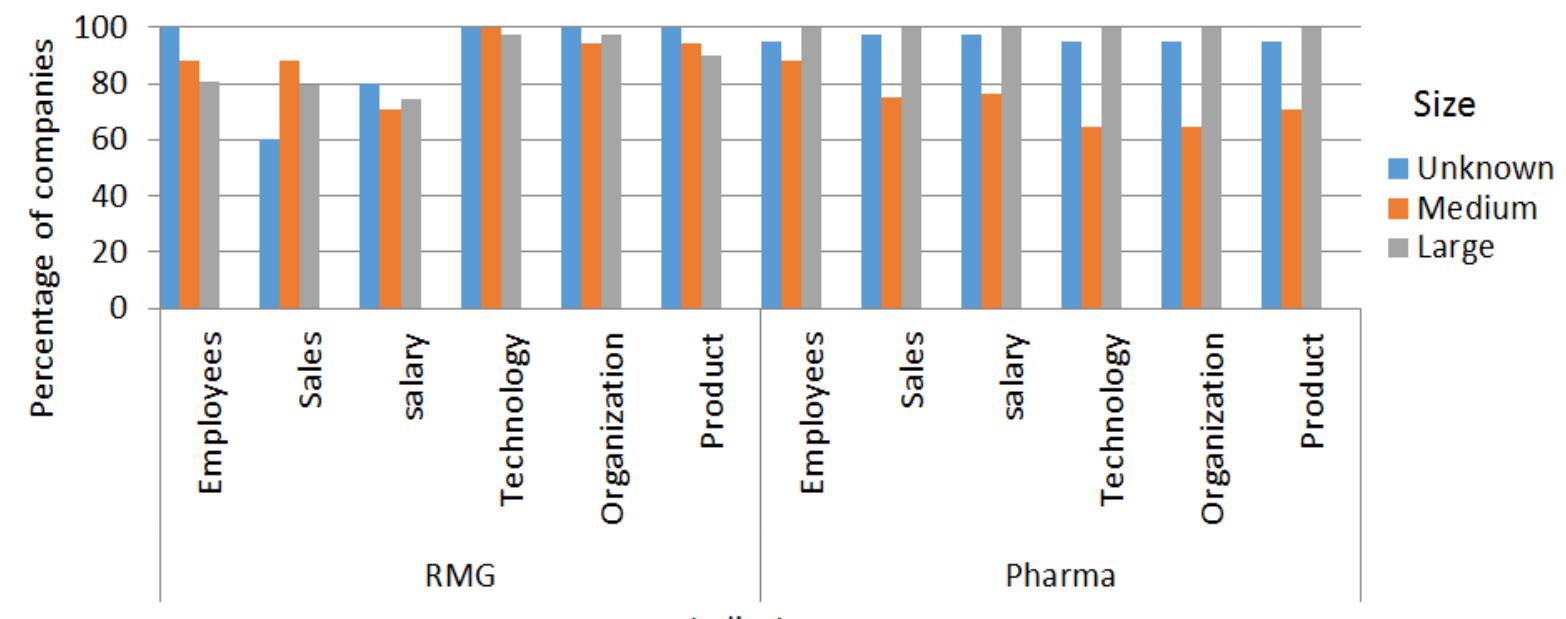

Indicators

Figure-2. Percentage of companies' showing positive trends in growth and transformation by size.

In the pharmaceutical industry, large companies performed significantly better, both in terms of growth and transformation indicators, than those of medium size. However, the situation is different for RMG companies: Company size does not seem to make a large difference here Figure 2.

\subsection{Skills Needs and Shortage}

Table 2 depicts workers skills needed as a consequence of transformation by the type of industry. It was observed that slightly more than half of companies (48\% in RMG and $57.1 \%$ in pharmaceuticals) needed workers with significantly more skills while more than two-fifths of the companies surveyed $(46 \%$ in RMG and $37.5 \%$ in pharmaceuticals) needed workers with somewhat more skills, indicating that a negligible proportion of industries needed either workers with the same skills as before or less skills. This implies that a skills gap exists for the industries surveyed, potentially caused by the growth and transformation occurring there.

Table-2. Proportion of companies by workers skills needs level and type of industry.

\begin{tabular}{|c|c|c|c|c|c|c|}
\hline \multirow{2}{*}{$\begin{array}{l}\text { Type of } \\
\text { industry }\end{array}$} & \multicolumn{5}{|c|}{ Workers skills needs level } & \multirow[t]{2}{*}{ Total } \\
\hline & $\begin{array}{c}\text { Significantly } \\
\text { less workers } \\
\text { skills }\end{array}$ & $\begin{array}{c}\text { Somewhat } \\
\text { less workers } \\
\text { skills }\end{array}$ & $\begin{array}{l}\text { Same workers } \\
\text { skills as before }\end{array}$ & $\begin{array}{c}\text { Somewhat } \\
\text { more workers } \\
\text { skills }\end{array}$ & $\begin{array}{c}\text { Significantly } \\
\text { more workers } \\
\text { skills }\end{array}$ & \\
\hline $\begin{array}{c}\mathrm{RMG} \\
(\mathrm{N}=100)\end{array}$ & $1.0 \%$ & $0.0 \%$ & $5.0 \%$ & $46.0 \%$ & $48.0 \%$ & $100 \%$ \\
\hline $\begin{array}{l}\text { Pharma } \\
(\mathrm{N}=61)\end{array}$ & $0.0 \%$ & $1.8 \%$ & $3.6 \%$ & $37.5 \%$ & $57.1 \%$ & $100 \%$ \\
\hline $\begin{array}{c}\text { All }(\mathrm{N}= \\
161)\end{array}$ & $0.6 \%$ & $0.6 \%$ & $4.5 \%$ & $42.9 \%$ & $51.3 \%$ & $100 \%$ \\
\hline
\end{tabular}

\subsection{Skills Shortage against Skills Needs}

On average $80 \%$ of companies ( $82 \%$ in RMG and $76 \%$ in pharmaceuticals) reported that they did not face any difficulties in finding employees for all occupational levels combined. However, when focussing on individual levels, companies acknowledged difficulties in filling technical positions at the operator, technician and to some extent higher management level. Particularly, pharmaceutical companies found it harder than RMG to find adequate employees.

Our data shows that $27 \%$ of companies (44\% pharmaceutical and $17 \%$ RMG) reported that they faced difficulties in finding skilled technicians, and $33 \%$ of companies (29\% pharmaceutical and $36 \%$ RMG) claimed the same for the operator level. Companies were also facing some difficulties in getting management-level employees. $17 \%$ of the surveyed companies (25\% pharmaceutical and $12 \% \mathrm{RMG}$ ) encountered challenges in finding these toplevel employees. Another $10 \%$ of companies faced difficulty finding skilled personnel for supervisor positions. On the upside, more than $90 \%$ of companies reported that they had no difficulties hiring general workers for easy tasks Figure 3. The data indicated a skills shortage at the important occupational levels of technician, operator, supervisor and higher management in the industries surveyed which affected their business operations and growth. 


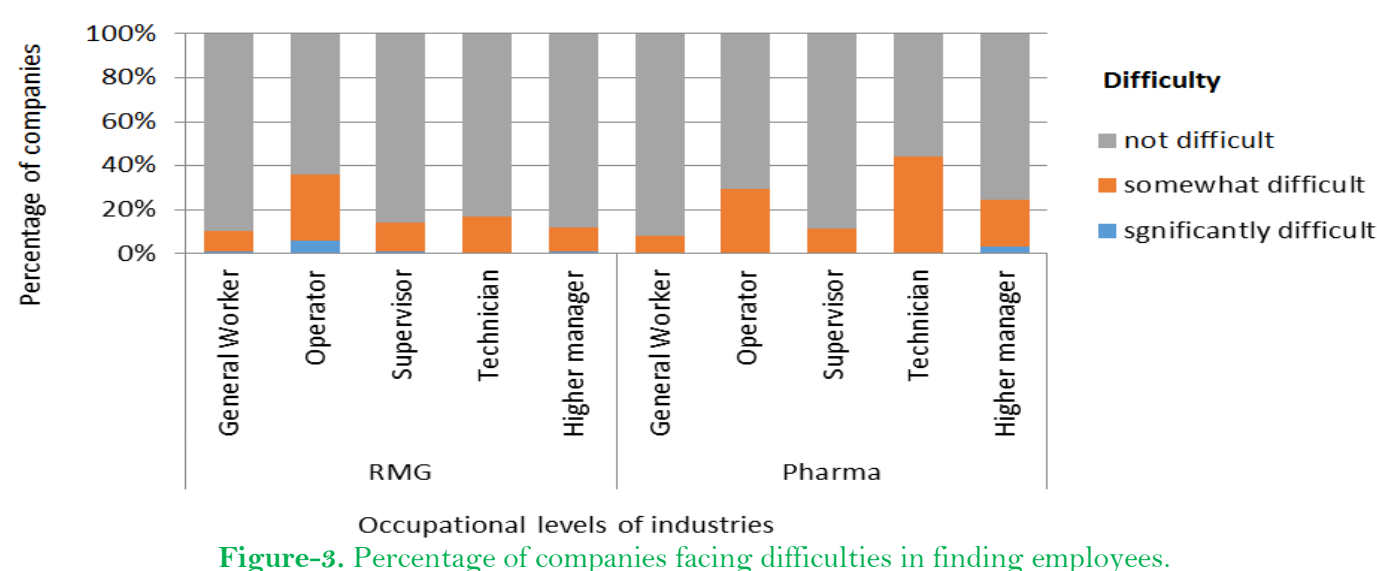

\subsection{Perceived Effects of Skills Shortage on the Business Operations, Growth and Expansion of Companies}

The development of a company depends partly on the company's organization of the production process, and skilled employees play a big role here. The survey data can support the claim that the lack of skilled employees directly impacts the operations and ultimately hinders the growth of the company.

Our data shows that $75 \%$ of the companies which encountered difficulties in hiring skilled personnel had the perception that a lack of skilled workers negatively impacted their operations and growth. In the RMG industry, more than $80 \%$ of companies reported that they faced difficulties in operating their business due to the shortage of skilled general workers, operators and managers and around $70 \%$ of companies thought that their growth was hampered at the same time. In the pharmaceutical industry, fewer companies (60\%) assumed that skills shortages (especially at technician, supervisor and general worker levels) affected their operations and growth Figure 4.

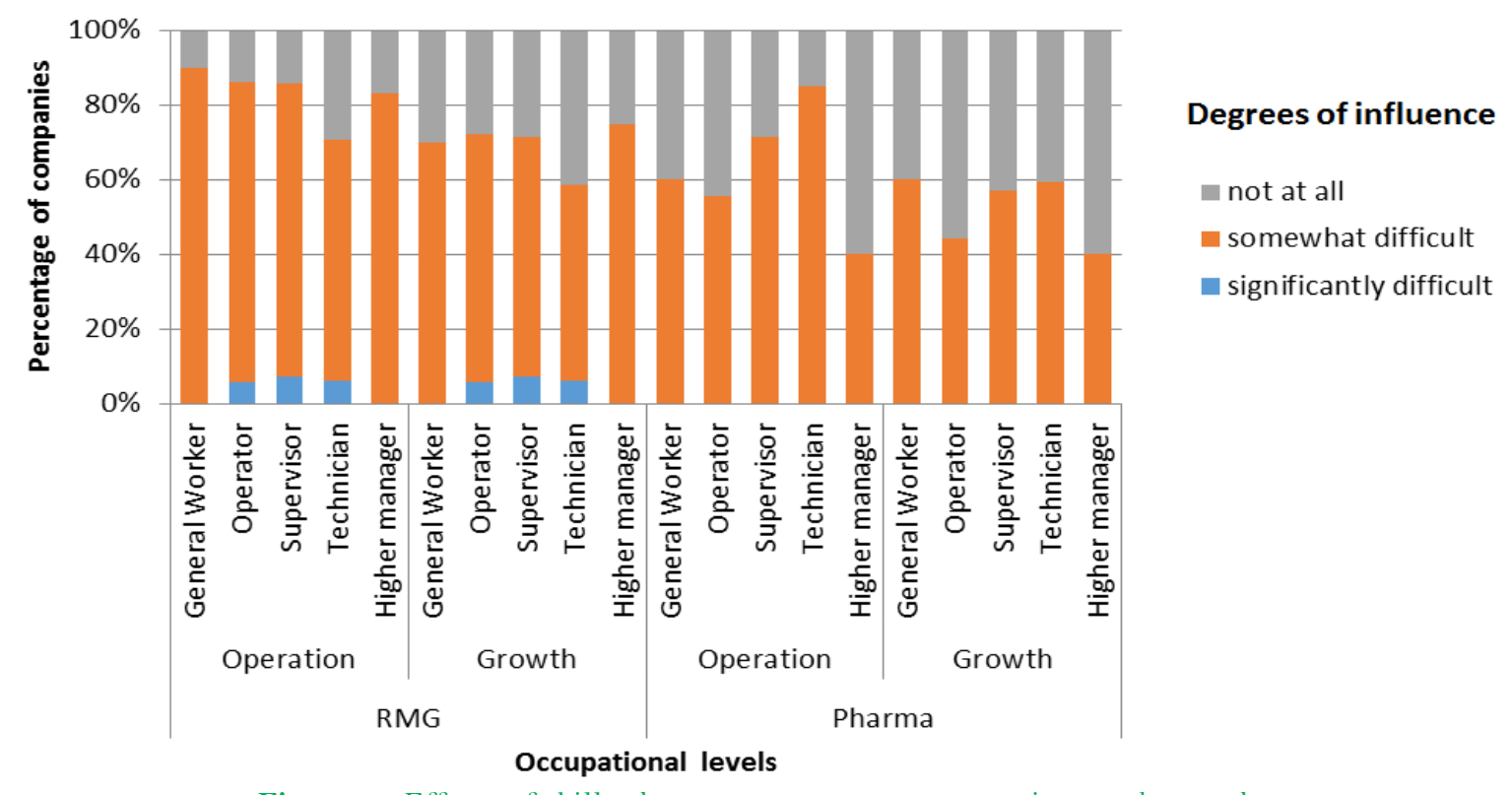

3.6. Skills Development Programs and Contribution to Meeting Skills Demand/Needs

Our data indicates that more than three-fourths of the companies surveyed had workers in lower level positions, who constitute the largest share of employees in these industries, with no experience of any TVET programs. On average less than $20 \%$ of companies had some workers with some experience of pre-employment and in-employment TVET programs in all occupational levels. This is with the exception of pre-employment TVET programs for technicians and higher management levels where the proportions were higher Figure 5.

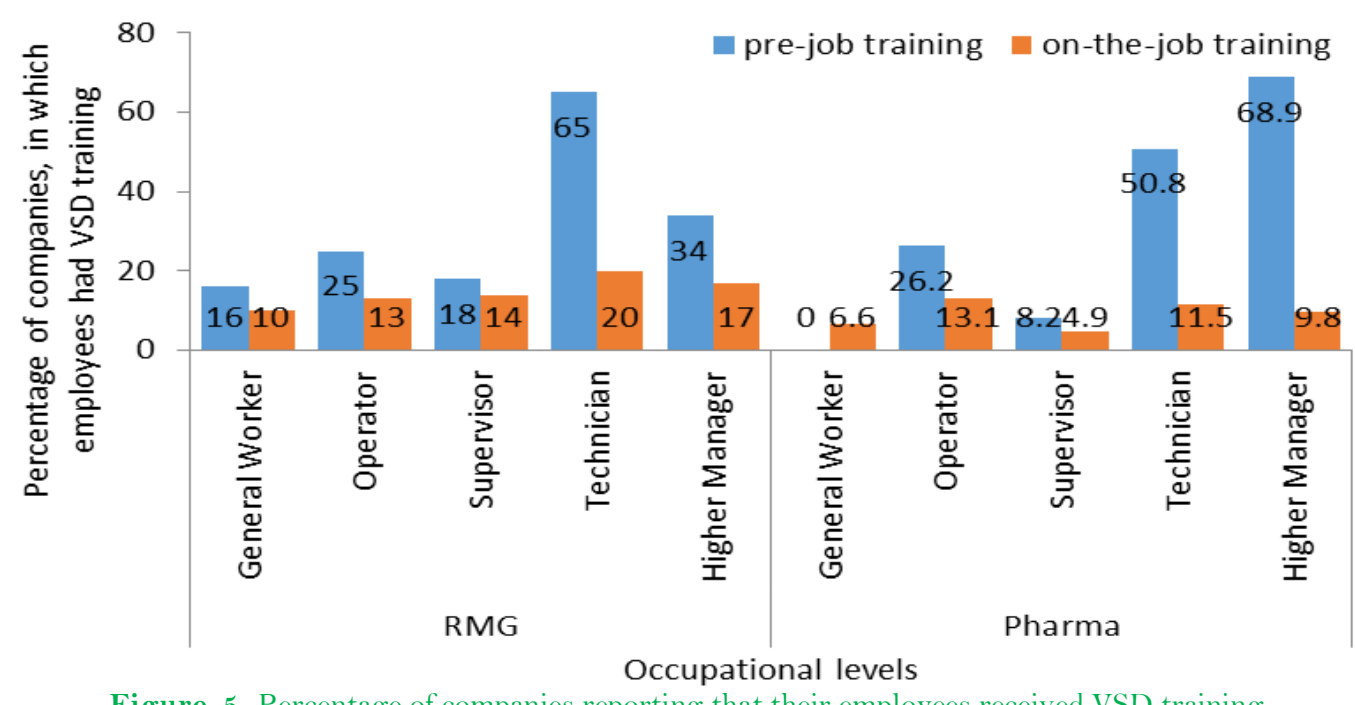

Figure-5. Percentage of companies reporting that their employees received VSD training. 
Based on company evaluations of the TVET programs which aimed to meet the skills requirements, TVET programs for lower levels of employees such as general workers, operators and supervisors, did not contribute significantly to the skills needs of the companies, and the level of contribution between pre-employment and inemployment TVET programs differed Table 3. Our data indicated the pre-employment TVET programs' contribution for all occupational positions as a 'Significant distribution' (198) higher than 'Somewhat distribution' (146). This difference is much higher for pharmaceutical (83 as opposed to 47) industries than that of RMG (115 as opposed to 99) indicating comparatively less contribution of TVET programs to the skills needs in RMG. If we examine this at different occupational levels, TVET programs' contribution were significant for mid- and higherlevel employees such as technicians and higher management. These likely represent diploma graduates of the polytechnic institutes, implying that other TVET programs, for the vast majority of employees at lower occupational levels in these industries, are not contributing significantly. This indicates a mismatch between TVET programs and the skills needs of these industries.

Table-3. The skills programs' contribution to meet the skills needs of companies.

\begin{tabular}{|c|c|c|c|c|c|c|}
\hline \multirow[t]{2}{*}{ Sector/Position } & \multicolumn{3}{|c|}{$\begin{array}{l}\text { Pre-employment skills programs' } \\
\text { contribution to meeting skills need }\end{array}$} & \multicolumn{3}{|c|}{$\begin{array}{c}\text { In-employment skills programs' } \\
\text { contribution to meeting skills need }\end{array}$} \\
\hline & No & Somewhat & Significantly & No & Somewhat & Significantly \\
\hline \multicolumn{7}{|l|}{ RMG } \\
\hline General worker & & 16 & & & 11 & \\
\hline Operator & & 24 & 4 & & 10 & 3 \\
\hline Supervisor & & 16 & 2 & & 12 & 2 \\
\hline Technician & 1 & 32 & 78 & & 12 & 12 \\
\hline Higher Management & & 11 & 31 & & 6 & 15 \\
\hline All positions RMG & 1 & 99 & 115 & & 51 & 32 \\
\hline \multicolumn{7}{|l|}{ Pharmaceuticals } \\
\hline General worker & & & & & & 5 \\
\hline Operator & & 7 & 13 & & 4 & 7 \\
\hline Supervisor & & & 6 & & & 3 \\
\hline Technician & 2 & 21 & 23 & & 5 & 9 \\
\hline Higher Management & 1 & 19 & 41 & & 2 & 7 \\
\hline All positions Pharmaceuticals & 3 & 47 & 83 & & 11 & 31 \\
\hline Total & 4 & 146 & 198 & & 62 & 63 \\
\hline
\end{tabular}

Overall, pre-employment TVET programs are considered to be better than in-employment TVET programs, however, while RMG industries found pre-employment TVET better, pharmaceutical industries had a better perception of in-employment TVET programs.

The following figures $(6 \& 7)$ show perceptions of the companies which reported having some employees with TVET training, about how useful they found such programs, on average. Considering the mean of the contribution of TVET programs with a maximum value of 2 , in both the cases of RMG and pharmaceutical industries (Figure 6), pre-employment TVET programs were found to be more beneficial for higher occupational levels (technician and higher management for RMG, and supervisor, technician and higher management for pharmaceuticals). Like pre-employment TVET programs, RMG industries found in-employment TVET programs more beneficial for higher occupational levels (technician and higher management), while in-employment TVET programs were found to be beneficial for all occupational levels in pharmaceutical industries, and better than in RMG industries (Figure 7). If we consider the number of TVET programs and their contribution level, the graphs show TVET programs' contribution was found to be significant for upper occupational levels, while significantly not meeting the skills need of the industries surveyed for lower level employees, indicating a mismatch between TVET programs for the vast majority of workers and the actual skills needs of these industries.

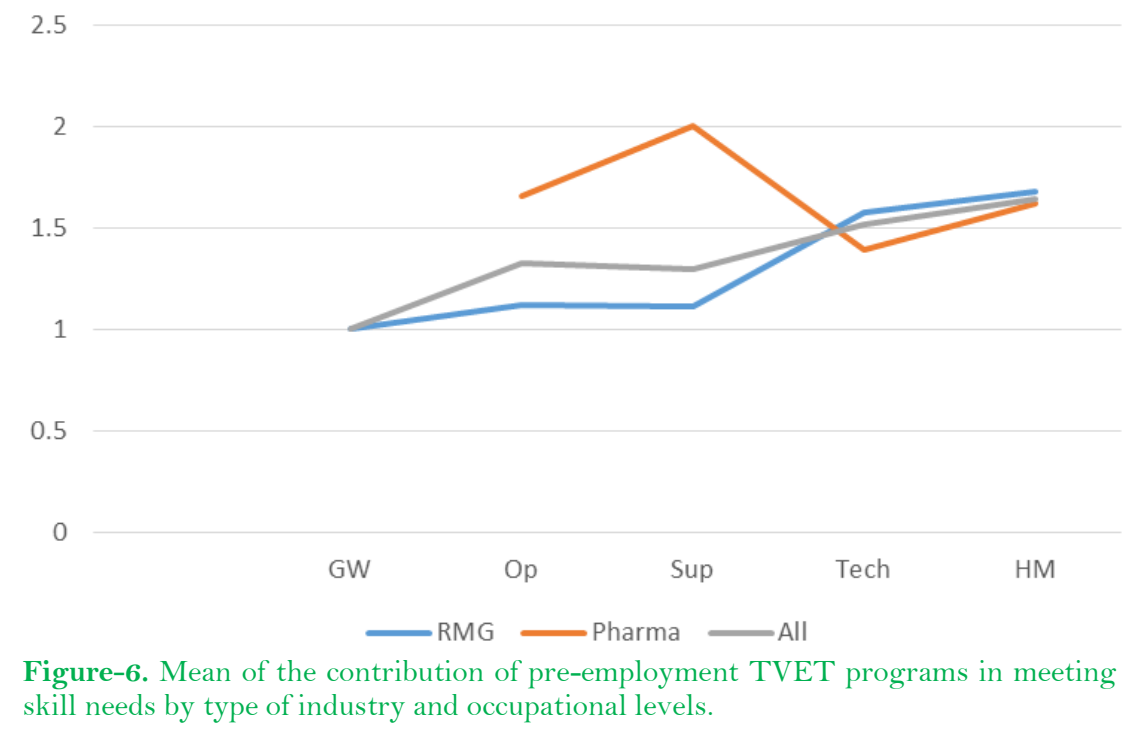

lil needs by type of ind 
2.5

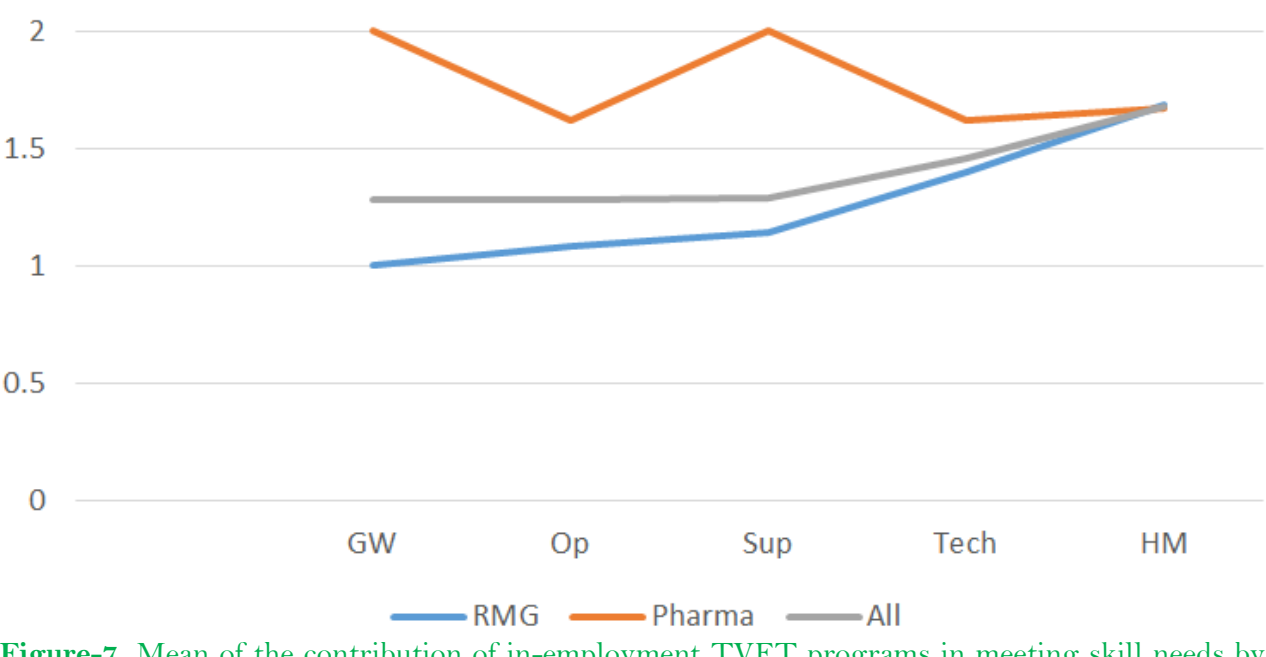

Figure-7. Mean of the contribution of in-employment TVET programs in meeting skill needs by

type of industry and occupational levels.

\subsection{Relation between TVET Programs' Contribution and Growth and Transformation}

Returning to the company perspective, Table 4 shows that a higher proportion of those companies which found TVET significantly useful $(84.7 \%)$ achieved growth compared to companies in the sample which found TVET somewhat useful $(56.7 \%)(\mathrm{p}<.001$, Chi square $=11.999, \mathrm{df}=1)$. However, the strength of this relationship between usefulness of TVET and industrial growth was found to be moderate $(\mathrm{Phi}=.271)$.

Table-4. Proportion of companies (RMG and pharmaceutical) by extent of growth and TVET program contribution.

\begin{tabular}{l|c|c|c}
\hline \multirow{2}{*}{ Extent of TVET contribution } & \multicolumn{2}{|c|}{ Proportion of companies by extent of growth } \\
\cline { 2 - 4 } & Companies have grown & Companies have not grown & $15.3 \%$ \\
\hline Companies found TVET significantly useful & $84.7 \%$ & $43.3 \%$ & $100 \%$ \\
\hline Companies found TVET somewhat useful & $56.7 \%$ & $20.5 \%$ & $100 \%$ \\
\hline Total & $79.5 \%$ & $100 \%$ \\
\hline
\end{tabular}

Note: $\mathrm{p}<0.001$, Chi square $=11.999, \mathrm{df}=1, \mathrm{Phi}=0.271$

Almost the same proportions of companies which found TVET significantly useful and somewhat useful experienced transformation through having become more complex Table 5 indicating evidence of no or insignificant difference hence no significant relationship between the usefulness of TVET and industrial transformation.

Table-5. Proportion of companies (RGM and pharmaceutical) by extent of transformation and TVET program contribution.

\begin{tabular}{|c|c|c|c|}
\hline \multirow[t]{2}{*}{ Extent of TVET contribution } & \multicolumn{2}{|c|}{ Proportion of companies by extent of transformation } & \multirow[t]{2}{*}{ Total } \\
\hline & $\begin{array}{c}\text { Companies have become more } \\
\text { complex }\end{array}$ & $\begin{array}{c}\text { Companies have not become } \\
\text { more complex }\end{array}$ & \\
\hline $\begin{array}{ll}\text { Companies found } & \text { TVET } \\
\text { significantly useful } & \end{array}$ & $93.9 \%$ & $6.1 \%$ & $100 \%$ \\
\hline $\begin{array}{l}\text { Companies found TVET somewhat } \\
\text { useful }\end{array}$ & $93.3 \%$ & $6.7 \%$ & $100 \%$ \\
\hline Total & $93.8 \%$ & $6.2 \%$ & $100 \%$ \\
\hline
\end{tabular}

A higher proportion Table 6 of RMG companies of those which found TVET significantly useful (81.6\%) achieved growth compared to those RMG companies in the sample which found TVET somewhat useful (50.0\%) shows a relationship $(\mathrm{p}<.002$, Chi square $=9.454, \mathrm{df}=1)$. However, the strength of this relationship between usefulness of TVET and industrial growth in RMG companies was found to be moderate (Phi $=.307$ ).

Table-6. Proportion of RMG companies by extent of growth and TVET program contribution.

\begin{tabular}{|c|c|c|c|}
\hline \multirow[t]{2}{*}{ Extent of TVET contribution } & \multicolumn{2}{|c|}{ Proportion of RMG companies by extent of growth } & \multirow[t]{2}{*}{ Total } \\
\hline & Companies have grown & Companies have not grown & \\
\hline $\begin{array}{l}\text { Companies found TVET significantly } \\
\text { useful }\end{array}$ & $81.6 \%$ & $18.4 \%$ & $100 \%$ \\
\hline $\begin{array}{l}\text { Companies found TVET somewhat } \\
\text { useful }\end{array}$ & $50.0 \%$ & $50.0 \%$ & $100 \%$ \\
\hline Total & $74.0 \%$ & $26.0 \%$ & $100 \%$ \\
\hline
\end{tabular}

Note: $\mathrm{p}<0.002$, Chi square $=9.454, \mathrm{df}=1, \mathrm{Phi}=0.307)$.

A small difference in the proportions of RMG companies which found TVET significantly useful (98.7\%) and those who found it somewhat useful (95.8\%) experienced transformation having become more complex Table 7 indicating an insignificant relationship between usefulness of TVET and industrial transformation with very small effect size $($ Phi $=.087)$. 
Table-7. Proportion of RMG companies by extent of transformation and TVET program contribution.

\begin{tabular}{|c|c|c|c|}
\hline \multirow[t]{2}{*}{ Extent of TVET contribution } & \multicolumn{2}{|c|}{ Proportion of RMG companies by extent of transformation } & \multirow[t]{2}{*}{ Total } \\
\hline & $\begin{array}{l}\text { Companies have become } \\
\text { more complex }\end{array}$ & $\begin{array}{c}\text { Companies have not become } \\
\text { more complex }\end{array}$ & \\
\hline $\begin{array}{l}\text { Companies found TVET significantly } \\
\text { useful }\end{array}$ & $98.7 \%$ & $1.3 \%$ & $100 \%$ \\
\hline $\begin{array}{l}\text { Companies found TVET somewhat } \\
\text { useful }\end{array}$ & $95.8 \%$ & $4.2 \%$ & $100 \%$ \\
\hline Total & $98.0 \%$ & $2.0 \%$ & $100 \%$ \\
\hline
\end{tabular}

Note: $\mathrm{p}<0.384$, Chi square $=0.756, \mathrm{df}=1$, Phi $=0.087$.

Although there are small differences in the proportions of pharmaceutical companies those which found TVET significantly useful and somewhat useful experienced growth and transformation having become more complex Table 8 \& 9 indicating an insignificant relationship between usefulness of TVET and industrial growth and transformation with very small effect size $(\mathrm{Phi}=.054 \& .035)$.

Table-8. Proportion of pharmaceutical companies by extent of growth and TVET program contribution.

\begin{tabular}{|c|c|c|c|}
\hline \multirow[t]{2}{*}{ Extent of TVET contribution } & \multicolumn{2}{|c|}{ Proportion of pharmaceutical companies by extent of growth } & \multirow[t]{2}{*}{$\overline{\text { Total }}$} \\
\hline & Companies have grown & Companies have not grown & \\
\hline $\begin{array}{l}\text { Companies found } \\
\text { significantly useful }\end{array}$ & $89.1 \%$ & $10.9 \%$ & $100 \%$ \\
\hline $\begin{array}{l}\text { Companies found } \\
\text { somewhat useful }\end{array}$ & $83.3 \%$ & $16.7 \%$ & $100 \%$ \\
\hline Total & $88.5 \%$ & $11.5 \%$ & $100 \%$ \\
\hline
\end{tabular}

Table-9. Proportion of pharmaceutical companies by extent of transformation and TVET program contribution.

\begin{tabular}{|c|c|c|c|}
\hline \multirow[t]{2}{*}{$\begin{array}{l}\text { Extent of } \\
\text { contribution }\end{array}$} & \multicolumn{2}{|c|}{$\begin{array}{c}\text { Proportion of pharmaceutical companies by extent of } \\
\text { transformation }\end{array}$} & \multirow[t]{2}{*}{ Total } \\
\hline & $\begin{array}{l}\text { Companies have become } \\
\text { more complex }\end{array}$ & $\begin{array}{c}\text { Companies have not become } \\
\text { more complex }\end{array}$ & \\
\hline $\begin{array}{l}\text { Companies found } \\
\text { significantly useful }\end{array}$ & $87.3 \%$ & $12.7 \%$ & $100 \%$ \\
\hline $\begin{array}{l}\text { Companies found TVET } \\
\text { somewhat useful }\end{array}$ & $83.3 \%$ & $16.7 \%$ & $100 \%$ \\
\hline Total & $86.9 \%$ & $13.1 \%$ & $100 \%$ \\
\hline
\end{tabular}

Note: $\mathrm{p}<0.786$, Chi square $=0.074, \mathrm{df}=1, \mathrm{Phi}=0.035$.

\section{Analysis}

Most of the companies surveyed showed a positive trend in all growth and transformation indicators. More than three-fourths of these companies reported that their number of employees, salaries and the volume of their sales increased over the last 5 years. Changes in technology, products and work organization were found in almost all companies. This could hint, especially for RMG, at specific upgrading strategies of companies to survive in a competitive global market. In the pharmaceutical industry large companies performed significantly better, both in terms of growth and transformation indicators, than those of medium size. However, the situation is different for RMG companies; company size does not seem to make large difference here. This suggests that future research is needed to understand why this might be.

Changes in technology, products and work organization created demand for workers with more skills than they had before. These industries faced difficulties finding low-level and mid-level employees. Finding technically skilled people proved especially difficult, and this affected their company's operations and growth somewhat negatively. This might indicate a lack of available TVET programs for preparing workers for these occupational levels or that these companies were sceptical of the quality of graduates from TVET programs at these levels. The proportion of non-technical employees (general workers, operators, lower- and mid- level supervisors with low skills or low TVET training) is much higher than technical and higher-level employees. This clearly indicated that a skills gap and skills shortage exist in these industries.

Most of the companies reported that a shortage of skilled employees at all levels affected the operations and growth of the companies and the growth of the companies' productivity. As Okorafor, Uduanochie, and Achukwu (2014) observed, in the context of global competition, countries with poor technical capacity cannot survive in an increasingly competitive world. Integration into the global economy requires skilled workers to meet the demands of local and international markets. Technological education plays a vital role in today's labour market as technological innovation and economic growth fuel demand for skilled workers. Current economic and technological changes demand highly skilled technologists for improved quality products and services.

On average less than $20 \%$ of the companies surveyed had workers with pre- and in-employment TVET training at all occupational levels, excepting pre-employment TVET programs for technicians and higher management levels, indicating that industries might not find adequately skilled persons for different occupational levels from the TVET institutes. TVET programs did contribute to filling the skills needs of these companies, however, they contributed significantly only for mid- and higher-level occupations (technician and higher management) in the case of pre-employment TVET programs. The fact in this case might be that these preemployment programs were diploma programs from the Polytechnic institutes and other engineering courses, indicating that industries were perhaps devaluing other TVET programs offered by many other institutions. These lower-status TVET programs are very much required for lower levels of workers who constitute more than threefourths of the total employees in industry. This sheds light on the mismatch between TVET programs for the majority of workers and the actual skills needs of the industries surveyed. 
Almost all technicians and higher managers have some form of pre-job TVET training/ educational degree and most of the companies did not arrange/provide on-the-job TVET training for them. Industry follows the learning by doing' approach and they argue that this is on-the-job training. Sometimes companies arrange in-house needsbased training for employees with the introduction of new machinery/technology but this is mainly for higher skilled workers and provided by the company that they procure the new technology from. During this training these higher skilled employees perform and practice these new tasks in order to be fully habituated in what could be compared with what Acemoglu and Restrepo (2018) describe as the standardization of new tasks created as a consequence of changes in technology. Then these experienced workers train the other low-skilled or unskilled workers to perform these tasks. However, the delay inherent to this process might hamper companies' productivity for some time.

Within the companies surveyed, of those whose employees received TVET training, the perception of the contribution of these TVET programs to meeting skills needs showed that there was a significant but a moderate relationship between level of contribution and company growth while the relationship between the level of contribution and company transformation was not significant and very weak. This indicates a mismatch between TVET programs and the skills needs of the industries surveyed. This might be due to lack of collaboration and communication between TVET providers and industry in Bangladesh.

\section{Conclusion}

The challenges facing TVET programs in Bangladesh have been highlighted in a number of studies (Ahmed, 2016; Asian Development Bank, 2011, 2015, 2016; Bangladesh Institute of Development Studies, 2017; Dewan \& Sarker, 2017; Hossain, 2018; Khan, 2019; Mia \& Karim, 2015; Raihan et al., 2017; World Bank, 2018). This research has contributed to this existing literature by demonstrating that there has been a moderate relationship between the level of contribution of TVET programs in the RMG and pharmaceutical industries and level of growth in industries, and this moderate contribution was mainly from the TVET programs for mid-and higherlevel employees. This further points to the majority of workers' lack of the workplace skills needed by the surveyed industries. The TVET sector in Bangladesh is yet to be prioritized and has faced a number of impediments, including skills shortages, a skills-gap, and a skills mismatch, that is, the mismatch between the supply of skills and the demand for skills The mismatch between the outputs of the TVET system and the needs of the employment sectors involve three dimensions: first, the trades or technologies being offered through training programs are not relevant to the world of employment; second, the competencies acquired in relation to the requirements of industries or self-employment opportunities are not sufficient; and third, a lack of opportunity for the learners to acquire practical experience and skills. Hence, there is a missing link between skill development and employment, that is, a lack of alignment between TVET and industries in Bangladesh.

To remedy this lack of alignment requires stronger collaboration and partnership between industry and TVET institutions in the quest of harnessing human resources for employment and the world of work. The Government must also firmly commit to implementing existing policies in this area. Close collaboration and partnership from government, TVET providers and industry is required so that they may understand the requirements of industry when designing TVET programs.

This study suggests further research is required on the causes and consequences of skills shortages, the skills-gap, and a skills mismatch.

\section{References}

Acemoglu, D., \& Restrepo, P. (2018). The race between man and machine: Implications of technology for growth, factor shares, and employment. American Economic Review, 108(6), 1488-1542.Available at: https://doi.org/10.1257/aer.20160696.

Ahmed, M. (2016). Matching education, training, skills and jobs. Su-editorial, Dhaka: The Daily Star.

Arntz, M., Gregory, T., \& Zierahn, U. (2016). The risk of automation for jobs in OECD countries: A comparative analysis (Vol. 189, pp. 0_1). OECD Social, Employment, and Migration Working Papers.

Asadullah, M. A., \& Ullah, A. Z. (2018). Social-economic contribution of vocational education and training : An evidence from OECD countries. Industrial and Commercial Training, 50(4), 172-184.Available at: https://doi.org/10.1 108/ict-12-2017-0100.

Asian Development Bank. (2011). Bangladesh: Skills for employment (Concept Paper). Project Number. 43466, Dhaka: Asian Development Bank.

Asian Development Bank. (2015). Innovative strategies in technical and vocational education and training for accelerated human resource development in South Asia: Bangladesh. Manila: Asian Development Bank.

Asian Development Bank. (2016). Skills development in Bangladesh (ADB Briefs No. 67). Manila: Asian Development Bank.

Bangladesh Institute of Development Studies. (2017). BIDS study report: labour market and skill gap in Bangladesh (micro and macro level study). Dhaka: Skills for Employment Investment Program. Finance Division, Ministry of Finance, The Government of the People's Republic of Bangladesh.

Bhattacharya, D., Raman, M., \& Raihan, A. (2002). Contribution of the RMG Sector to the Bangladesh Economy. CPD Working Paper 50, Centre for Policy Dialogue.

Bhuiyan, M. N. U., Hakim, M. A., \& Alam, M. F. (2015). Competitiveness and global prospects of pharmaceutical industries in Bangladesh: An overview. The Cost and Management, 47(5), 10- 22.

Brettel, M., Friederichsen, N., Keller, M., \& Rosenberg, M. (2014). How virtualization, Decentralization and network building change the manufacturing landscape: An Industry 4.0 Perspective. International Scholarly and Scientific Research छ Innovation, 8(1), 37-44.

Dewan, S., \& Sarker, U. (2017). From education to employability: A case study of Bangladesh. New Delhi: JustJobs Network Inc and UNICEF South Asia.

Export Promotion Bureau. (2017). Annual report 2016-2017. Dhaka: EBP, Ministry of Commerce, Government of the People's Republic of Bangladesh.

Frey, C. B., \& Osborne, M. (2013). The future of employment. How susceptible are jobs to computerization? Working Paper. Oxford: Oxford Martin Programme on Technology \& Employment, University of Oxford.

Frey, C., \& Rahbari, E. (2016). Do labor-saving technologies spell the death of jobs in the developing world? Paper presented at the 2016 Brookings Blum Roundtable, Aspen, Colorado, in the Report 'The Future of Work in the Developing World 2016 Brookings Blum Roundtable report', Washington DC: Brookings Institute.

Government of Bangladesh. (2009). A national technical and vocational qualification framework for Bangladesh: Short form proposal submitted to ILO and European Union under TVET refor project. Dhaka: Ministry of Education, Government of the People's Republic of Banglades.

Government of Bangladesh. (2010a). Outline perspective plan of Bangladesh 2010-2021: Making vision 2021 a reality. Dhaka: General Economics Division, Planning Commission, Government of The People's Republic of Bangladesh. 
Government of Bangladesh. (2010b). National education policy 2010. Dhaka: Ministry of Education, Government of the People's Republic of Bangladesh, Dhaka.

Government of Bangladesh. (2010c). Skills and training enhancement project: Project Introduction in Bangla. Dhaka: Directorate of Technical Education (DTE), Technical and Madrasha Education Division, Ministry of Education, Government of the People's Republic of Bangladesh.

Government of Bangladesh. (2011). Bangladesh Skills Development Policy 2011. Dhaka: Ministry of Education, Government of the People's Republic of Bangladesh, Dhaka.

Government of Bangladesh. (2014). Non-formal education (NFE) Act 2014 (in Bangla). Dhaka: Legislative and Parliamentary Affairs Division. Ministry of Law, Justice and Parliamentary Affairs, Government of the People's Republic of Bangladesh.

Government of Bangladesh. (2015a). Seventh five year plan FY2016- FY2020: Accelerating growth. Empowering Citizens, Dhaka: General Economic Division, Planning Commission, Government of the People's Republic of Banhladesh.

Government of Bangladesh. (2015b). Bangladesh Labour Act 2006, Bangladesh Gazette, 28 September 2015. Dhaka: Legislative and Parliamentary Affairs Division, Ministry of Law, Justice and Parliamentary Affairs, Government of the People's Republic of Bangladesh.

Government of Bangladesh. (2015c). Skills for employment investment program: At a glance. Dhaka: Finance Division, Ministry of Finance, Government of the People's Republic of Bangladesh, Dhaka.

Government of Bangladesh. (2016a). Bangladesh industrial policy 2016. Dhaka: Ministry of Industries. Government of the People's Republic of Bangladesh.

Government of Bangladesh. (2016b). The expatriates welfare and overseas employment policy 2016, in Bangla. Dhaka: Ministry of Expatriates Welfare and Overseas Employment, Government of the People's Republic of Bangladesh.

Government of Bangladesh. (2018b). Bangladesh technical education board Act 2018. Dhaka: Technical and Madrasha Education Division, Ministry of Education, Government of the People's Republic of Bangladesh.

Heath, R., \& Mobarak, A. M. (2015). Manufacturing growth and the lives of Bangladeshi Women. Journal of Development Economics, $115(\mathrm{C})$, $1-15$.

Hossain, M. N. A. (2018). Skills mismatch in new industrial frontier. Sub-editorial, Dhaka: The Financial Express.

Hossain, M. M., \& Shoaib, S. M. (2014). Role of pharmaceutical sector in the national economy of Bangladesh. World Journal of Pharmacy and Pharmaceutical Sciences, 3(2), 951-960.

Jabarullah, N. H., \& Hussain, H. I. (2019). The effectiveness of problem-based learning in technical and vocational education in Malaysia. Education + Training, 61(5), 552-567.Available at: https://doi.org/10.1108/et-06-2018-0129.

Khan, D. A. (2019). Situation analysis of Bangladesh TVET Sector: A background work for a TVET SWAp. Skills 21 study, ILO Regional Office, Bangkok: ILO.

Lee, H. S., Har, W. M., \& Lee, S. Y. (2020). Impacts of lower and upper secondary vocational education on economic growth, in. Journal of Technical Education and Training, 12(1), 76-81.Available at: https://doi.org/10.30880/jtet.2020.12.01.008.

Mankiw, N. G., Romer, D., \& Weil, D. N. (1992). A contribution to the empirics of economic growth. The Quarterly Journal of Economics, $107(2), 407-437$

Mcgrath, S., \& Powell, L. (2016). International Journal of Educational Development Skills for sustainable development: Transforming vocational education and training beyond 2015. International Journal of Educational Development, 5o(C), 12-19.

Melaiye, O. R., Amuchie, A. A., \& Glory, J. K. (2019). The role of technical and vocational education in national development. Global Journal of Human-Social Science: H Interdisciplinary, 19(5), 1.0.

Mia, A., \& Karim, M. R. (2015). Survey of TVET providers Bangladesh. Dhaka: National Skills Development Council Secretariat.

Mitra, A., \& Sharma, C. (2020). Employment, impact of technologies in the developing world. Chapter in Handbook of Labor Human Resurces and Population Economics Springer Link, 1- 18.

Mostafa, R., \& Klepper, S. (2017). Industrial development through tacit knowledge seeding: Evidence from the Bangladesh garment industry. Management Science, 64(2), 613-632.Available at: https://pubsonline.informs.org/doi/10.1287/mnsc.2016.2619.

Mottaleb, K. A., \& Sonobe, T. (2011). An inquiry into the rapid growth of the garment industry in Bangladesh. GRIPS Discussion Paper 1110, Tokyo: National Graduate Institute for Policy Studies, 7- 22- 1 Roppongi, Minato-ku, Tokyo, Japan.

Okorafor, O. A., Uduanochie, C. A., \& Achukwu, C. B. (2014). Sustainable mechanism for involving industries in technology education for economic. Development, in World Educators Forum, 4(1), $2350-2401$.

Paton, R. M., Fluck, A. E., \& Scanlan, J. D. (2018). Engagement and retention in VET MOOCs and online courses: A systematic review of literature from 2013 to 2017. Computers \& Education, 125, 191-201.Available at: 10.1016/j.compedu.2018.06.013.

Petrillo, A., De Felice, F., Cioffi, R., \& Zomparelli, F. (2018). Fourth industrial revolution: Current practices, challenges, and opportunities. Digital Transformation in Smart Manufacturing, Petrillo, A., Cioffi, $R$. $छ$ De Felice, F., IntechOpen.Available at: http://dx.doi.org/10.5772/intechopen.72304.

Raihan, S., \& Khan, S. S. (2020). Structural transformation, inequality dynamics, and inclusive growth in Bangladesh. UNU-WIDER Working Paper 2020/44, Helsinki: United Nations University World Institute for Development Economics Research.

Raihan, S., Lemma, A., Khondokar, B. H., \& Ferdous, F. B. (2017). Bangladesh sectoral growth diagnostic. A Research Paper on Economic Dialogue on Inclusive Growth in Bangladesh The Project was led by Overseas Development Institute in conjunction with The Asia Foundation.

Reich, M. R. (1994). Bangladesh pharmaceutical policy and politics. Health Policy and Planning, 9(2), 130-143.Available at: https://doi.org/10.1093/heapol/9.2.130.

Siddiky, M. R., \& Uh, S.-B. (2020). Linking TVET with industries in Bangladesh: Need for Supportive Policies and an Approach to TVET. Journal of Technical Education and Training, 12(3), 1-21.Available at: https://doi.org/10.30880/jtet.2020.12.03.001.

Sultana, J. (2016). Future prospects and barriers of phamaceutical industries in Bangladesh. Bangladesh Pharmaceutical Journal, 19(1), 5557.Available at: https://doi.org/10.3329/bpj.v19i1.29239.

Sungsup, R., Shrestha, U., Khatiwada, S., Yoon, S. W., \& Kwon, K. (2019). The rise of technology and impact on skills. International Journal of Training Research, 17(1), 26-40.

Tazin, F. (2016). Pharmaceutical industry of Bangladesh: Progress and prospects. The Millennium University Journal, 1(1), 19- 30.

UN. (2015). Transforming our world: The 2030 agenda for sustainable development. New York: United Nations.

World Bank. (2018). Bangladesh Development Update: Building on resilience. Dhaka: The World Bank Office. 